\title{
Stunting Knowledge on the Prevention of Babies with BBLR in the PKU Muhammadiyah Yogyakarta Hospital
}

\author{
Retno Mawarti ${ }^{1, *}$ \\ University of Aisyiyah Yogyakarta, West Ringroad 63 Street Nogotirto, Gamping Sleman 55292, Yogyakarta, \\ Indonesia \\ ${ }^{1}$ retnomawarti55@gmail.com* \\ * corresponding author \\ Submission date: 1 Juli 2020, Receipt date: 5 Juli 2020, Publication date: 1 November 2020
}

\begin{abstract}
One of the problems suffered by toddlers is stunting caused by low birth weight (LBW). The number of stunting incidents in Indonesia in 2016 was 27.5\% (Ministry of Health, 2016), while the incidence of stunting in Yogyakarta in 2016 was 14.4\% Stunting can lead to poor motor and mental development at an early age, as well as poor cognitive presentations and school presentations in advanced childhood (Nutrition Section of the DIY Health Office, 2014). One of the efforts to prevent stunting is to see the knowledge of mothers about stunting. The purpose of this study was to determine the Knowledge Description of Stunting Prevention in mothers with LBW children at PKU Muhammadiyah Hospital Yogyakarta. This research uses a descriptive quantitative method. The study population was mothers who had LBW children with a total sample of 25 respondents who were drawn using a purposive sampling technique. The research instrument used a questionnaire and the analysis used a percentage. The results of this study show that maternal knowledge about LBW in the moderate category is 14 (56\%) and the poor category is 11 (44\%). The maternal knowledge about stunting, in the good category is 209 (80\%), and in the fair category is 5 (20\%). The maternal knowledge on prevention of stunting in $L B W$ babies in the good category is 22 (88\%), and in the poor category is $3(12 \%)$. In the future, it is hoped that mothers with low birth weight babies can increase their knowledge of stunting prevention.
\end{abstract}

Keywords: Low Birth Weight, Preventive Knowledge, Stunting

\section{INTRODUCTION}

Stunting is a short or very short body condition that occurs as a result of malnutrition and recurring disease for a long time in the fetus stage until the first 2 years of a child's life (Black et al, 2008). Stunting is a disorder of the linear growth of the child's body to become short or very short based on height for age with a threshold (Z-score) <- 2 SD. It is influenced by nutritional problems in every life cycle, starting in the womb (fetus), infants, especially babies with LBW, children, until adults. The period of the first two years of life is critical because growth and development is very rapid in this period. Nutritional disorders that occur during this period are permanent, it cannot be reversed even though the nutritional needs are met in the next period. (Ministry of Health, 2010) Across the world, there are 171 million children under five $(23.8 \%)$ or one in four children under five years of age experiencing stunted growth. Indonesia is one of the top five countries in the world with a high incidence of stunting, and highest compared to 
other Southeast Asia countries (MCA, 2015). Based on Riset Kesehatan Dasar (Riskesdas) it is estimated in 2013 that more than one-third or more than 8.9 million children under 5 years old in Indonesia experience growth below international standard measures for height. The stunting rate in Yogyakarta for the prevalence of stunting and very short under 5 years old in 2015 was $10.36 \%$, increasing to $14.4 \%$ in 2016 (Ministry of Health, 2016). According Provincial Health Office of D.I Yogyakarta (2016), the largest incidence of short children under 5 years old was in Yogyakarta City District at $17.57 \%$ and followed by Kulon Progo Regency at $14.87 \%$.

Indirectly, the incidence of stunting is also influenced by socio-economic factors such as education level, income, and several household members (Soetjining sih, 2012). One of the risk factors that affect the incidence of stunting in children under five is a history of low birth weight (LBW) (Proverawati and Ismawati, 2010). As a result, the growth of LBW babies will be disrupted, if this situation continues with insufficient feeding, frequent infections, and poor health care can cause stunted children.

Many people think that the main cause of having short children is genetic or hereditary factors. But the truth is, only $5 \%$ children influenced by hereditary. The rest are caused by nutritional intake, parenting styles, and environmental conditions. During pregnancy, several things need to be followed to reduce stunting in children, such as the guarantee of nutritional intake, exclusive breastfeeding until two years old, the parenting style must be good, and the cleanliness of the environment. (Jukardi, 2015).

In the short term, stunting can lead to poor motor and mental development in early childhood, followed by poor cognitive and school performance in later stages. While the long term continues to show worse performance, stunting sufferers experience oxidation disorders, resulting in a lot of fat on the adipose tissue and resulting in obesity in children. (Nutrition Section of the DIY Health Office, 2014). According to research conducted by Yuniarti (2012) there is a relationship between stunting status and learning achievement.

The global target in reducing stunting in the Sustainable Development Goals (SDGs) is to end all forms of malnutrition, including achieving the international target of 2025 by reducing the prevalence of stunting by $40 \%$ or $22.3 \%$ per year or reducing the stunting rate of 171 million by 2010 to around 100 million by 2025 . However, considering the current progress, it is estimated that the decline will only reach $26 \%$ so that around 127 children will be stunted in 2025, therefore efforts are made quite hard to reduce the stunting rate (Onis, 2013).

$70 \%$ of stunting occurs in the first 1000 days of life, $30 \%$ are between 2 and 5 years of age (Andrew, 2014). Globally, various programs to prevent and reduce stunting have been launched, one of them is the Essential Nutrition Action (ENAs) by WHO. One of the ENAs programs is the provision of healthy nutrition for women as an effort to prepare for pregnancy as early as possible for women who want to become pregnant. The Indonesian government also launched the "First 1000 Days of Life Movement" (1000 HPK) in September 2012 which aims to accelerate the improvement of nutrition to improve the lives of Indonesian children in the future. This movement involves various sectors and policymakers to work together to reduce the prevalence of stunting and other forms of malnutrition in Indonesia (MCA, 2015). Minister of Health Regulation (Permenkes) Number 28 of 2017 in article 18 letter b states that midwives are authorized to provide health services to children. Furthermore, in article 20 paragraph 2 letter $\mathrm{c}$ the authority is to monitor the growth and development of babies, toddlers, and pre-school children. 
Decree of the Ministry of Health of the Republic of Indonesia Number 1995/MENKES/SK/XII/2010 concerning Anthropometric Standards for Assessment of the Nutritional Status of Children has established an index for the assessment of the nutritional status of children based on body weight, age, and height. In addition, the government has made regulations regarding exclusive breastfeeding for the fulfillment of nutrition for infants including complementary foods in accordance with Indonesian Government Regulation Number 33 of 2012 concerning exclusive breastfeeding must be given for the first 6 months without accompanied by any foods.

Apart from the role of the government and health workers, the role of parents, especially those who have children with LBW, about the prevention of stunting is also very much expected. So far, Integrated Healthcare Center (Posyandu) is the only a place where people expect services from the government and will lose participation when the government is no longer involved. People are used to getting everything from the government, people do not see that personal health, the health of their communities and their groups should be their responsibility too (Kalsum, 2015).

Based on a preliminary study conducted at PKU Muhammadiyah Hospital Yogyakarta before, it was found that in one month, there are 8-10 babies treated with LBW. Most of their mothers did not know the prevention of stunting in their babies which would likely occur if they were not given nutritious food, especially exclusive breastfeeding until the age of 6 months and complementary breastfeeding at the age of 7-35 months, complete immunization, stimulation of growth and development properly. Based on those backgrounds, researchers are interested in taking research on the Stunting Knowledge on The Prevention of Babies with BBLR in The PKU Muhammadiyah Yogyakarta Hospital in 2019.

\section{RESEARCH METHODS}

The research method used is descriptive research in which the researchers describe the research activities carried out on certain objects clearly and systematically (Sukardi, 2003). In this study, this research aims to know the description of the knowledge of mothers who have LBW about the prevention of stunting at the Muhammadiyah Hospital Yogyakarta. Univariate variables used are breastfeeding up to 6 months, PMT 6-35 months, Immunization, and Environment.

An operational definition is defining variables operationally based on observed characteristics, allowing researchers to make observations or measurements carefully of an object or phenomenon (Hidayat, 2009). The definition of knowledge on prevention of stunting in mothers with LBW children is that knowledge is the result of knowing, and this occurs after people sense a certain object. What is meant by the researcher here is the level of knowledge about: Exclusive breastfeeding 1-6 months, provision of additional food for 6- 35 months, immunization, and the environment with a range of scores as follows:

a. Good: Score $>76 \%-100 \%$

b. Fair: Score $56 \%-75 \%$.

c. Poor: Score $<56 \%$

The population in this study were 30 mothers who had children with LBW who were being treated at the Muhammadiyah Hospital Yogyakarta from November 2019 to January 2020. While the samples taken in this study were mothers who had LBW children. 
The sampling technique used in this study was the "purposive sampling" technique, which is a sampling technique with certain considerations based on predetermined inclusion and exclusion criteria (Sugiyono, 2015).

Inclusion criteria in this study such as: mothers who have children LBW 15002499 grams, agree to be research subjects, and who can read and write

Exclusion criteria in this study such as:mother or baby suddenly gets worse/ill/dies, LBW babies with congenital defects/abnormalities. The data in this study obtained through primary data using data collection tools in the form of questionnaires to be filled in by respondents themselves. There are few questions to determine the level of knowledge of stunting prevention in mothers with LBW children including: Exclusive breastfeeding (5 questions), complementary breastfeeding (5 questions), Immunization (5 questions), Environment (5 questions).

Univariate analysis was performed after tabulation and the frequency of each category was then calculated for the percentage by using the formula:

\section{RESULTS AND DISCUSSION}

The characteristics of the respondents in this study were divided into several groups, including age, education, occupation of the respondent, husband's occupation, parity, pregnancy distance, type of delivery, and mother's BMI which can be seen in Table 1 below:

Tabel 1. Characteristics of respondents frequency distribution based on age, education, maternal occupation, husband's occupation, parity, pregnancy distance, type of delivery, mother's BMI, and

\begin{tabular}{|c|c|c|c|}
\hline \multicolumn{3}{|c|}{ comorbidities } & Doroontoro (O) \\
\hline \multirow{4}{*}{ Ages } & & Frequencies (In) & Percentage (\%) \\
\hline & $<20$ yo & 1 & 4 \\
\hline & $20-35$ yo & 17 & 68 \\
\hline & $>35$ yo & 7 & 28 \\
\hline \multirow{4}{*}{$\begin{array}{l}\text { Educational } \\
\text { Background }\end{array}$} & Elementary School & 1 & 4 \\
\hline & Junior High School & 1 & 4 \\
\hline & Senior High School & 14 & 78 \\
\hline & College/University & 9 & 36 \\
\hline \multirow{2}{*}{$\begin{array}{l}\text { Mother's } \\
\text { Occupancy }\end{array}$} & Unemployed & 11 & 44 \\
\hline & Employed & 14 & 56 \\
\hline \multirow{3}{*}{$\begin{array}{c}\text { Father's } \\
\text { Occupancy }\end{array}$} & Civil Servant & 4 & 16 \\
\hline & Private Employees & 2 & 8 \\
\hline & Entrepreneur & 19 & 76 \\
\hline \multirow{2}{*}{ Parity } & Primiparous & 3 & 12 \\
\hline & Multiparous & 22 & 88 \\
\hline \multirow{2}{*}{$\begin{array}{l}\text { Antenatal Care } \\
\text { (ANC) }\end{array}$} & Regular & 25 & 100 \\
\hline & Irregular & 0 & 0 \\
\hline \multirow{2}{*}{ Comorbidities } & Yes & 6 & 24 \\
\hline & No & 19 & 76 \\
\hline
\end{tabular}

Source: Primary Data, 2020

Based on the table above, it can be seen that the characteristics of the respondents are quite diverse. When viewed by age, the majority of mothers aged 20-35 years were 17 people (68\%), and at least less than 20 years old, namely 1 person (4\%). Meanwhile, when viewed from an education perspective, the highest level of education is high school senior high school as many as 14 people (78\%), tertiary institutions as many as 9 people (36\%), and at least SD and SMP 1 person (4\%). Based on occupation, the 
majority were mothers who did not work as many as 14 people (56\%), while the jobs of fathers were mostly self-employed as many as 19 people $(76 \%)$, and at least as many as 2 people $(2 \%)$ as private employees. In terms of parity, the majority of mothers were multiparous as many as 22 people (88\%) and primiparous as many as 3 peoples $(12 \%)$,. All respondents as many as 25 people $(100 \%)$ performed pregnancy checks (Antenatal Care/ANC) regularly. Finally, when viewed from comorbidities, as many as 6 people (24\% had comorbidities.

Knowledge is the result of knowing and occurs after people sense certain objects. Most of the human knowledge is obtained through the eyes and ears. Knowledge or cognition a very important domain for the formation of social action (Notoadmodjo, 2002). An individual's knowledge is influenced by several factors, including age, education, occupation, and information. Age greatly affects someone's knowledge. The older a person is, the more his knowledge increases, moreover if it's supported by education and information from the mass media.

Meanwhile, Low Birth Weight (LBW) is a baby born weighing less than 2,500 grams regardless of gestation (Atikah, 2010). WHO defines all newborns with a birth weight of less than 2,500 grams as Low Birth Weight Infants (LBW). LBW can be caused by the duration of pregnancy and the fetal growth rate. Babies with birth weight less than 2,500 grams can be caused by born prematurely or because of growth retardation (Paramitha, 2012). The health condition and the nutritional status of the mother's during pregnancy can affect fetal growth and development. Mothers who experience chronic energy deficiency or anemia during pregnancy will give birth to babies with Low Birth Weight (LBW) (Keefe, 2008 in Yusdarif, 2017).

Based on a survey of respondents, the following results were collected:

Tabel 2. Frequency Distribution of Mother's Knowledge about LBW at PKU Muhamadiyah Hospital Yogyakarta

\begin{tabular}{ccc}
\hline Categories & Frequencies (n) & Percentage (\%) \\
\hline Good & - & - \\
\hline Fair & 14 & 56 \\
\hline Poor & 11 & 44
\end{tabular}

Source: Primary Data, 2020

In Table 2 above, the results show that the knowledge of mothers about LBW in the fair category was 14 people (56\%) and 11 people (44\%) had less knowledge. Based on these data, it can be concluded that there are no mothers categorized as having good knowledge. The knowledge of mothers with low birth weight babies has the potential for stunting in the short and long term because one of the factors that influence the occurrence of stunting is LBW. Nani (2015) shows there is a significant relationship between LBW to the incidence of stunting in children under five.

The results of this study are also in line with the research of Yusdarif (2017), which shows that there is a significant relationship between LBW and the incidence of stunting in children aged 24-59 months. Toddlers with a history of LBW have a chance of 1, 31 times more likely to experience stunting than children born at normal weight. Rahayu (2015) also shows that low birth weight is the most dominant risk factor associated with the incidence of child stunting in the Puskesmas Sungai Karias area, Hulu Sungai Utara, South Kalimantan. Another study conducted by Loida (2017), states that there is a relationship between birth weight and the incidence of stunting at the age 
of 0-59 months in the central region of Mozambique. LBW reflects malnutrition very early in a child's life and requires more attention in the days to come. Children who suffer from malnutrition with LBW and are stunted during adolescence and adulthood will experience poor and long-lasting growth problems as a malnutrition cycle (Ranuh, 2013).

Stunting or too short for age is a height that is below minus two standard deviations (<-2SD from the WHO child growth standard nutritional status table). Short toddler (stunting) is a nutritional status based on the $\mathrm{PB} / \mathrm{U}$ or $\mathrm{TB} / \mathrm{U}$ index wherein anthropometric standards the assessment of children's nutritional status and measurement results are at the threshold (Z-Score) between -2 SD to -3 SD categorized as short/stunted and <-3 SD categorized as very short/severely stunted (Ministry of Health, 2016).

Stunting occurs when the fetus is still in the womb and appears when the child is two years old. This relates to the growth period in the first 1,000 days of life (Hari Pertama Keliharan/HPK), particularly pregnant women, nursing mothers, and children 0-23 months. The 1,000 HPK period covers 270 days during pregnancy and the first 730 days after the baby is born, this period has been scientifically proven to be the period that determines the quality of life. This period is called the "golden period" or the "critical period", and the World Bank in 2006 called it the "window of opportunity". One of the bad effects that can be caused by nutritional problems in that period is stunting (MCA Indonesia, 2016). This is similar to studies in Bangladesh, India, and Pakistan where the children aged 24-59 months were found to be at a greater risk of being stunted, as this suggests that children aged 24-59 months are stunted due to their irreversible nature (Ramli, 2009).

Tabel 3. Frequency Distribution of Mother's Knowledge about stunting at PKU Muhamadiyah Hospital Yogyakarta

\begin{tabular}{ccc}
\hline Categories & Frequencies $(\mathbf{n})$ & Percentage (\%) \\
\hline Good & 20 & 80 \\
\hline Fair & 5 & 20 \\
\hline Poor & - & - \\
\hline
\end{tabular}

Source: Primary Data, 2020

In Table 3, the results show that the mothers' knowledge about stunting was in a good category as many as 20 people (80\%), 5 people (20\%) sufficient, and none of them had less knowledge. This data shows that the knowledge of mothers about stunting is quite good. This can be influenced by the educational characteristics of mothers, most of whom have a high school education (14 people (78\%) and tertiary institutions as many as 9 people (36\%). According to Notoatmodjo (2012), the higher a person's education, the easier it is to understand something about an object, in this case about stunting, the causes, and impacts of stunting. Besides education, age also plays an important role, wherein this study most of the productive age, namely 20-35 years as many as 17 people (\%), and working mothers as many as 14 people (56\%). Working mothers often get information from colleagues and also often get counseling from the institution where the mother works. Another factor is also influenced by the experience where 22 respondents in this study $(88 \%)$ had given birth or had more than one child or were called multiparous. 
Tabel 4. Frequency Distribution of Mother's Knowledge about stunting prevention at PKU Muhamadiyah Hospital Yogyakarta

\begin{tabular}{ccc}
\hline Categories & Frequencies (n) & Percentage (\%) \\
\hline Good & 22 & 88 \\
\hline Fair & - & - \\
\hline Poor & 3 & 12 \\
\hline
\end{tabular}

Source: Primary Data, 2020

Table 4 shows that based on the mother's knowledge of stunting prevention, there were 22 people $(88 \%)$ in the good category, 3 people $(12 \%)$ have inadequate knowledge, and nobody in the fair category. The wrong answer of some mothers (5 people / 20\%) is that LBW babies do not need to be routinely checked and after 6 months do not need to be given additional food and 1 person (4\%) answered that LBW babies do not need to be immunized. Prevention of stunting requires both prenatal and postnatal interventions. Preparation of the nutritional condition of mothers before pregnancy and childbirth, preparation for breastfeeding, promotion of exclusive breastfeeding should be conveyed to couples of childbearing age as well as couples who are getting married. In addition to preparing for pregnancy, regular prenatal examinations can also prevent the incidence of stunting. In this study, 25 women $(100 \%)$ of women had regular checkups.

Maternal health care after childbirth needs close attention so that mothers can provide exclusive breastfeeding for 6 months (Rahayu, 2011). The prevention proclaimed by the WHO in the Essential Nutrition Actions (ENAs) includes 6 things, namely: providing healthy nutrition for women, exclusive breastfeeding at 0-6 months, giving healthy supplementary foods to babies 6-35 months, provide food to sick toddlers, prevent iodine deficiency, and prevent iron deficiency anemia. Infants with LBW are no exception to get adequate nutritional intake by being given exclusive breastfeeding and additional food after 6 months. The provision of complete immunization is also a prevention of disease, LBW babies have less immune power so that immunization is expected to increase their immune power so that babies are prevented from infectious diseases.

Maxwell's theory (2011) states that malnutrition and infection often occur at the same time. Malnutrition can increase the risk of infection, whereas infection can lead to malnutrition. Children who are malnourished, have low body resistance to disease, get sick easily and their illness can lead to less nutrition, thus reducing their body's ability to fight disease. This is known as malnutrition infection.

Babies born with low birth weight (LBW) will experience obstacles in their growth and development as well as the possibility of deterioration in their intellectual function. Also, babies are more susceptible to infection and hypothermia. This condition needs to be addressed from an early age considering that low birth weight is one of the most common public health problems in poor and developing countries which is closely related to mortality and morbidity for newborns. Malnutrition prevention interventions are very meaningful for mothers during the pregnancy process. Prospective pregnant women must prepare nutrition before pregnancy and pregnant women must pay attention to nutrition during pregnancy to avoid babies born with LBW. 


\section{CONCLUSION}

Based on the results of research that have been conducted regarding the Stunting Knowledge in mothers with LBW babies at the PKU Muhammadiyah Yogyakarta Hospital 2019/2020, the following conclusions can be drawn:

1. The mother's knowledge about LBW in the moderate category is $14(56 \%)$ peoples and the poor category is $11(44 \%)$ peoples.

2. The mother's knowledge about stunting in the good category is 209 (80\%) peoples, and in the fair category is $5(20 \%)$ peoples.

3. The mother's knowledge on the prevention of stunting in LBW babies in the good category is $22(88 \%)$ peoples, and in the poor category is $3(12 \%)$ peoples.

Furthermore, there are 2 recommendations that can be proposed. For Respondents, it is recommended for mothers who have LBW babies to better prepare for their children's growth and development by increasing knowledge about stunting prevention, especially the need to provide additional food after the baby is more than 6 months old. Also, it's important to check their growth and development and give immunizations. As well as for PKU Muhammadiyah Yogyakarta Hospital, it is recommended to increase counseling on Stunting Prevention for mothers who have LBW children.

\section{REFERENCES}

Atikah P dan Cahyo, IS. (2010). Berat Badan Lahir Rendah (BBLR). Yogyakarta: Nuha Medika

Black R. E., Allen L. H., Bhutto ZA., de Onis M., Ezzati M., Mathers C. and Rivera J. (2008). Maternal And Child Undernutrition: Global and Regional Exposures and Healt Consequences. The Lancet Series. www.thelancet.com

Departemen Kesehatan RI. (2010). Profil Kesehatan Indonesia. Jakarta: Departemen Kesehatan RI.

Hidayat.(2014). Metode Penelitian Kebidanan dan Analisi Data Contoh Aplikasi Study Kasus.Jakarta: Salemba Medika

Jukardi, A. (2015). Anak Balita Pendek, Bukan karena Gen tetapi Kurang Gizi. Available from: http://www.pikiran-rakyat.com/hson/2015/02/25/317685/anakbalita-pendek-bukan-karena-gen-tetapi--kurang-gizi\&hl=id-ID Diakses tanggal 20 Oktober 2017 pukul 13:00 WIB

Onis, Mercedes de, Kathryn G. Dewey, Elaine Borghi, AdelheidW. Onyango, Monika Blossner, Bernadette Daelmans, et al (2013). The World Health Organization's Global forReducing Chilhood Stunting by 2025: rationale and Proposed Actions

Kalsum, Ummi., Jahari, Abas Basuri. (2015). Strategi Menurunkan Prevalensi Gizi Kurang Pada Balita di Provinsi Jambi. Jambi Medical Journal, Volume 3, Nomor 1, Mei 2015

Loida, et.al. (2017). Factors Associated with Stunting among Children Aged 0 to 59 Months from the Central Region of Mozambique. Nutrients 2017, 9, 491; doi:10.3390/nu9050491. www.mdpi.com/journal/nutrients, diperoleh tanggal 20 Mei 2018)

Notoadmodjo, S. (2012) Metodologi Penelitian Kesehatan. Jakarta: Rineka Cipta.

Maxwell, S. (2011). Module 5: Cause of Malnutrition. https://www.unscn.org/web/archives-resources/files/Policy-paper-No-5.pdf, diperoleh tanggal 25 November 2017)

MCA, M. C. C. (2015) 'Stunting dan Masa Depan Indonesia', in. Indonesia. 
MCA Indonesia. (2016). Stunting dan Masa Depan Indonesia. http://www.mcaindonesia.go.id/assets/uploads/media/pdf/Backgrounder-Stunting-ID.pdf, diperoleh tanggal 22 Oktober 20

Nani Hamdanah, (2018) Faktor-Faktor yang Berhubungan Dengan Kejadian Stunting Pada Balita Di Kelurahan Kricak. Kota Yogyakarta

Notoadmodjo, S. (2012) Metodologi Penelitian Kesehatan. Jakarta: Rineka Cipta.

Paramitha A. (2012). Faktor-faktor yang Berhubungan dengan Kejadian Stunting pada Balita 25-60 Bulan di Kelurahan Kalibata Depok Tahun 2012. Skripsi. Fakultas Kesehatan Masyarakat. Universitas Indonesia. http://lib.ui.ac.id/file?file=digital/20320460-S-Paramitha\%20Anisa.pdf, diperoleh tanggal 06 November 2017)

Proverawati, A dan Ismawati, C. (2010) BBLR (Berat Badan Lahir Rendah). Yogyakarta: Nuha Medika.

Rahayu. (2011). Hubungan Pendidikan Orang Tua dengan Perubahan Status Stunting dari Usia 6-12 Bulan Ke Usia 3-4 Tahun. Thesis. Yogyakarta :Universitas Gadjah Mada

Rahayu, Atikah., Fahrini Yulidasari., Andini Octaviana., Fauzie Rahman. (2015). Riwayat Berat Badan Lahir dengan Kejadian Stunting Pada Anak di Bawah Dua Tahun. Jurnal Kesehatan Masyarakat Nasional Vol. 10, No. 2, November 2015. Available from http://dx.doi.org/10.21109/kesmas.v10i2.888

Ramli, Kingsley EA, Kerry JI, Steven JB, Jennifer J and Michael JD. (2009). Prevalence and Risk Factors For Stunting and Severe Stunting Among UnderFives in North Maluku Province of Indonesia. BMC Pediatrics. Vol.9(64). 1-10

Ranuh, IG.N. GDE. (2013). Beberapa Catatan Kesehatan Anak. Jakarta: Sagung Seto

Seksi Gizi Dinas Kesehatan DIY. (2014). Peta Situasi Gizi DIY tahun 2013. DIY: Dinkes DIY.

Soetjiningsih. (2012) Tumbuh Kembang Anak. Jakarta: Buku Kedokteran EGC.

Sugiyono. (2015) Metode Penelitian Kuantitatif Kualitatif dan R\&D. Bandung: Alfabeta.

Yuniarti, A.M. (2012). Status Stunting dengan Prestasi Belajar Siswa Sekolah Dasar Di Kecamatan Sukodono Kabupaten Sidoarjo Tahun 2012. Tesis. Yogyakarta: Universitas Gadjah Mada.

Yusdarif. (2017). Determinan Kejadian Stunting pada Balita Usia 24-59 Bulan di Kelurahan Rangas Kecamatan Banggae Kabupaten Majene Tahun 2017. Skripsi. Universitas Islam Negeri Alauddin Makasar. http://www.repo-sitori.uinalauddin.ac.id/8113/1/YUSDARIF.pdf, diperoleh tanggal 17 Mei 2018) 